\title{
ANALYSIS OF TRAINING METHOD OF TAEKWONDO ATHLETES WITH REACTION BALL
}

ANÁLISE DO MÉTODO DE TREINAMENTO DE ATLETAS DE TAEKWONDO COM BOLA DEREAÇÃO ANÁLISIS DEL MÉTODO DE ENTRENAMIENTO DE ATLETAS DE TAE KWON DO CON PELOTA DE REACCIÓN

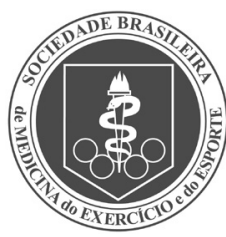

Original Article ARTIGO ORIGINAL Artículo Original
Wei Zong 1,2 (1D

(Physical Education Professional)

1. Central China Normal University, School of Physical Education, Wuhan, Hubei, China. 2. NanJing Vocational Institute of Transport Technology, Physical Education Department, Nanjing, Jiangsu, China.

\section{Correspondence:}

Wei Zong. Wuhan, Hubei, China. 430079 .

hzsfzongwei@mails.ccnu.edu.cn

\begin{abstract}
Introduction: Brief introduction: Taekwondo is a sport that integrates explosive power and reaction speed. The reaction speed of the athletes has a direct bearing on the result of the competition. Objective: To improve the reaction time effect of athletes. Methods: Forty-one Taekwondo team athletes were selected as the research subjects. Then, the training methods were introduced, and special technology using an emg tester and a synchronous camera system was implemented to analyze the earliest emg signals and the moment of the hit, the time from signal emergence to the emg reaction for reaction time, and from signal emergence to hit for the total time. Results: The average score of the 41 athletes before the test was 0.282673 , with standard deviation of 0.0377349 and standard error of 0.0058932 . The average score, standard deviation, and standard error of the 41 athletes after small training were $0.28217,0.037744$ and 0.005895. Conclusions: From the test results of the three training modes, the small training mode had a significant impact on the reaction time of Taekwondo athletes, while the medium and large training modes did not have significant effects. The results show that a small amount of training is best and plays a significant role in improving the reaction of an athlete. Level of evidence Il; Therapeutic studies - investigation of treatment results.
\end{abstract}

Keywords: Martial arts; Reaction time; Academic training.

\section{RESUMO}

Introdução: Introdução breve: O Taekwondo é um esporte que incorpora força explosiva e velocidade de reação. A velocidade de reação dos atletas tem influência direta sobre o resultado da competição. Objetivo: Melhorar o efeito do tempo de reação dos atletas. Métodos: Quarenta e um atletas de equipes de Taekwondo foram selecionados como participantes da pesquisa. A seguir, foram introduzidos os métodos de treinamento e uma tecnologia especial usando um testador EMG e foi implementado um sistema de câmera sincrônica para analisar os primeiros sinais do EMG e o momento da batida, o tempo desde a emergência do sinal até a reação EMG para verificar tempo de reação e da emergência do sinal atéa batida para verificar o tempo total. Resultados: O escore médio dos 41 atletas antes do teste foi de 0,282673, com desvio padrão de 0,0377349 e erro padrão de 0,0058932. O escore médio, desvio padrão e erro padrão dos 41 atletas depois de um pequeno treinamento foram 0,28217, 0,037744 e 0,005895, respectivamente. Conclusões: A partir dos resultados dos testes dos três modos de treinamento, o modo de treinamento pequeno teve impacto significativo no tempo de reação dos atletas de Taekwondo, enquanto os modos de treinamento médio e grande não tiveram efeitos significativos. Os resultados mostram que uma pequena quantidade de treinamento é melhor e tem papel significativo na melhora da reação dos atletas. Nível de Evidência ll; Estudos terapêuticos - Investigação dos resultados do tratamento.

Descritores: Artes marciais; Tempo de reação; Treino acadêmico.

\section{RESUMEN}

Introducción: Breve introducción: El Tae Kwon Do es un deporte que incorpora fuerza explosiva y velocidad de reacción. La velocidad de reacción de los atletas influye directamente en el resultado de la competición. Objetivo: Mejorar el efecto del tiempo de reacción de los atletas. Métodos: Se seleccionaron 41 atletas de equipos de Tae Kwon Do como participantes de la investigación. A continuación, se introdujeron los métodos de entrenamiento y una tecnología especial que utiliza un probador EMGy se implementó un sistema de cámaras sincrónicas para analizar las primeras señales EMG yel momento del golpe, el tiempo desde la aparición de la señal hasta la reacción EMG para verificar el tiempo de reacción y desde la aparición de la señal hasta el golpe para verificar el tiempo total. Resultados: La puntuación media de los 41 atletas antes de la prueba fue de 0,282673, con una desviación estándar de 0,0377349 y un error estándar de 0,0058932. La puntuación media, la desviación estándary el error estándar de los 41 atletas tras una breve sesión de entrenamiento fueron de 0,28217, 0,037744 y 0,005895, respectivamente. Conclusiones: A partir de los resultados de las pruebas de los tres modos de entrenamiento, el modo de entrenamiento pequeño tuvo un impacto significativo en el tiempo de reacción de los atletas de Tae Kwon Do, mientras que los modos de entrenamiento mediano y grande no tuvieron efectos significativos. Los resultados demuestran que una pequeña cantidad de entrenamiento es mejory desempeña un papel importante en la mejora del tiempo de reacción de los atletas. Nivel de Evidencia ll; Estudios terapéuticos - Investigación de los resultados del tratamiento.

Descriptores: Artes marciales; Tiempo de reacción; Técnica de Entrenamiento. 


\section{INTRODUCTION}

In recent years, with the continuous development of taekwondo, taekwondo has achieved better results internationally. ${ }^{1}$ In taekwondo competition, athletes should not only have good physical fitness, but also have quick reaction speed. ${ }^{2}$ Taekwondo mainly uses hands and feet to knock down opponents through fierce confrontation. ${ }^{3}$ This requires the athletes to make reasonable use of offensive and defensive techniques during the competition, not only to avoid the opponent in time, but also to grasp the opportunity to get the score. ${ }^{4}$ There are many factors affecting the reaction speed of taekwondo athletes, including external factors and internal factors, and most of the external factors are not controllable, so only the internal factors affecting the reaction speed of taekwondo athletes are analyzed. In the process of reaction speed training, it is not necessary to blindly strengthen the exercise, but to enrich the means of training, so as to improve the reaction speed of athletes and achieve better results. ${ }^{5}$ On the basis of current research, this paper puts forward the training methods and effects of high-level taekwondo athletes, this method uses 41 taekwondo team athletes of the heavy competition management center as the research object, firstly, it introduces the training means and passes the myoelectric tester and synchronous camera system, analysis of the athlete's earliest emergence of emg signal and hit time, from signal emergence to emg reaction for reaction, from emg reflection to hit for movement, from signal emergence to hit for the total time of special technology. The results show that the average score of the 41 athletes before the test is 0.282673 , the standard deviation is 0.0377349 , and the standard error is 0.0058932 . The average score, standard deviation and standard error of the 41 athletes after small training were $0.28217,0.037744$ and 0.005895 . It shows that the training effect of small amount of training has significant effect on improving the response of athletes. ${ }^{6}$

\section{METHOD}

\section{Research object}

Taking taekwondo athletes of a provincial competition management center as the research object. The basic information is shown in Table 1.

\section{Training methods}

\section{Password exercises}

It is the most commonly used method in taekwondo reaction speed training. It refers to the training in which the coach uses simple language signals or sound signals to stipulate a certain or a group of technical movements of the athletes. For example, make specific actions (horizontal kick, down chop, double fly, etc.) quickly in response to the voice of the coach, or practice forward, backward, running, jumping, etc., after hearing the signal.?

\section{Number, direction and color change exercises}

Refers to in the training, according to the coach to show the number, direction and color of the different, the athletes quickly make a predetermined movement. Since numbers and colors are not closely related to taekwondo techniques, athletes must make judgments after being stimulated by these signals. ${ }^{8}$ Such a quick and instant transformation training has a good training effect on the athletes' on-the-spot reaction in actual combat, and also has a strong training effect on the athletes' observation.

Table 1. Basic information of taekwondo team athletes of The Heavy Competition M management center.

\begin{tabular}{c|c|c|c|c}
\hline Group & $\begin{array}{c}\text { The number } \\
\text { of cases }\end{array}$ & Average age & Average height & $\begin{array}{c}\text { Years of } \\
\text { training }\end{array}$ \\
\hline Man & 27 & $13-25$ & $170-198$ & $0.1-8$ \\
\hline Women & 14 & $15-23$ & $155-184$ & $1-5$ \\
\hline
\end{tabular}

\section{Shoulder touch exercises}

Refers to the athletes and partners in training, one of the hands touch the shoulder of the other side, the athletes according to its intention to quickly attack, defense, counter attack.

\section{Dummy simulation exercises}

Athletes in the training process, the use of dummy or other substitutes as imaginary enemies, dodge, change to block and all kinds of leg training. On the basis of this kind of training, according to the change of technique and the effective offensive action of the athletes, the rapid response of the movement.

\section{Practice more sling or drop ball}

According to the training requirements, hang 2-5 straps or balls in the designated space of the training ground. Training by hitting each sling or ball, so that it regularly swing. In this case, the athlete should do various dodging movements or technical movements, while paying attention to avoid the impact of the sling or the drop ball. In this changeable situation, athletes need to have good judgment ability, the ability to control the center of gravity of the body and the ability to move quickly. Therefore, coaches can train according to this method to improve the reaction speed of athletes.

\section{Softball throwing practice}

Softball throwing practice is when the coach throws a softball or tennis ball to hit the effective scoring part of the player's body. In this process, athletes actively adjust their steps and make corresponding action responses according to the speed and distance of the coach throwing the ball. Pay attention to this kind of training, the coach can according to the athletes training level, in accordance with the principle of step by step, gradually increase the training difficulty. For example, we can increase the strength of throwing and speed up the speed of throwing, so that athletes can react quickly in such a changeable situation.

\section{Target holding practice}

In taekwondo training, whether basic training or higher training, foot target is an essential prop, is one of the main means to improve the skill and tactics level of taekwondo athletes. In response speed training, because of the different training purpose, the form is also different.

\section{RESULTS}

The relationship between visual selection response and athletic performance

The athletes were divided into the group with sports achievements and the group without sports achievements for statistical analysis, as shown in Figure 1.

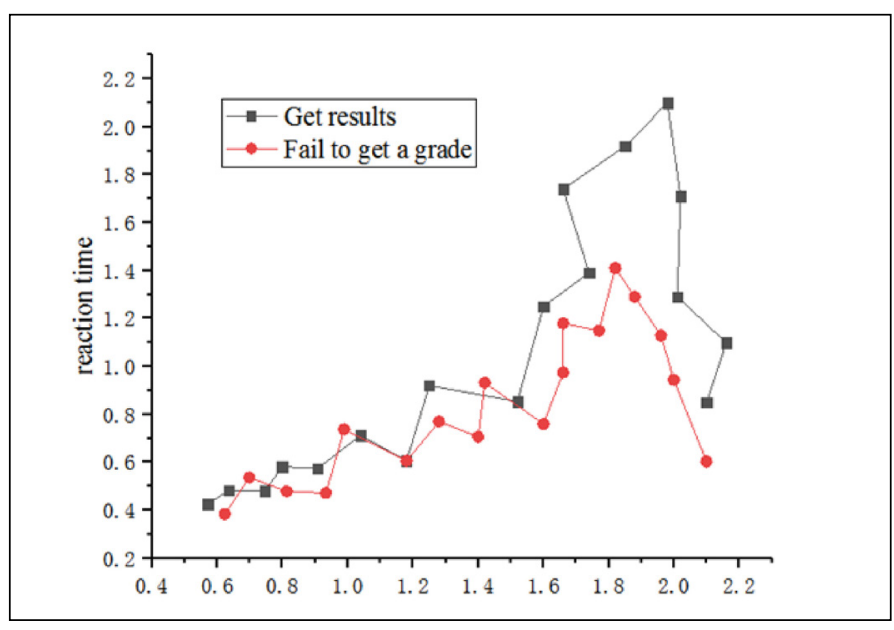

Figure 1. Results of visual selection response. 
It can be seen from Figure 1 that there is a significant statistical difference between the visual selection responses of athletes who have achieved results and those who have not achieved results, athletes with faster visual selection response time are more likely to achieve results, and faster visual response time is one of the key factors to overcome the enemy.

\section{Visual selection of sports and sports performance}

The athletes with and without sports achievements were divided into groups, and their visual selection responses were compared, as shown in Table 2.

As can be seen from Table 2, there is a significant statistical difference between the visual selection of athletes who have achieved sports results and those who have not, the athletes who have achieved sports performance are obviously faster than those who have not achieved sports performance, that is, the athletes who are fast in visual selection movement are also relatively easier to achieve sports performance.

\section{Comparison of total time of male and female taekwondo athletes}

After the taekwondo athletes were divided into male and female groups, the total time of single movement measured by reaction time tester was analyzed, and the comparison was obtained in Table 3.

It can be seen from Table 3 that there is no difference in the mean total time for male and female taekwondo athletes to complete a single test by visual reaction tester, that is, male athletes are not faster than female athletes in this instrument test. ${ }^{9}$

\section{DISCUSSION}

\section{Comparative analysis of response between groups under different forms of training}

As can be seen from Table 4, the average score of 41 athletes before the test is 0.282673 , the standard deviation is 0.0377349 , and the standard error is 0.0058932 . The average score, standard deviation and standard error of the 41 athletes after small training were $0.28217,0.037744$ and 0.005895 . It can be concluded that: The training effect is best with a small amount of training. ${ }^{10}$

Table 2. Relationship between sports performance and sports time.

\begin{tabular}{c|c}
\hline Group & When motion \\
\hline An athlete who has achieved athletic success & $0.18-4.11$ \\
\hline An athlete who has not yet achieved athletic results & $0.21-4.11$ \\
\hline
\end{tabular}

Table 4. Basic descriptive statistics of athletes' reactions before and under different training forms.

\begin{tabular}{c|c|c|c|c}
\hline & mean & $\mathbf{N}$ & Deviation & Error \\
\hline Pre-test reaction & 2.82673 & 41 & 0.377345 & 0.058932 \\
\hline Small training response & 2.8217 & 41 & 0.37744 & 0.05895 \\
\hline Medium dose response & 2.82420 & 41 & 0.377215 & 0.058911 \\
\hline Large training response & 2.82359 & 41 & 0.377280 & 0.058921 \\
\hline
\end{tabular}

Table 3. Total time comparison of male and female taekwondo athletes.

\begin{tabular}{c|c}
\hline Group & $\begin{array}{c}\text { Mean total time to complete } \\
\text { word test actions }\end{array}$ \\
\hline A male taekwondo athlete & $0.5-6.18$ \\
\hline A female taekwondo athlete & $0.5-5.16$ \\
\hline
\end{tabular}

\section{CONCLUSION}

This method uses 41 taekwondo team athletes of the heavy competition management center as the research object, firstly, the training means are introduced, through the emg tester and the synchronous camera system, the earliest emg signal and the time of the athlete's hit were analyzed, from the signal to the emg reaction, from emg reflection to hit for movement, from the signal to hit for the total time of special technology. The results show that the average score of the 41 athletes before the test is 0.282673 , the standard deviation is 0.0377349 , and the standard error is 0.0058932 . The average score, standard deviation and standard error of the 41 athletes after small training were $0.28217,0.037744$ and 0.005895 . From the analysis of the test results of three kinds of training amount, small training amount has significant effect on the response time of taekwondo athletes, while medium training amount and large training amount have no significant effect on the response time of taekwondo athletes. It shows that the training effect of small amount of training is the best and has significant effect on improving the response of athletes. At present, there are few researches on the training methods of high level taekwondo reaction speed, and systematic and in-depth understanding has not yet been formed. Therefore, it is hoped that taekwondo researchers pay more attention to the study of reaction speed training, in order to provide some reference for taekwondo coaches in reaction speed training.

The author declare no potential conflict of interest related to this article

\section{REFERENCES}

1. Moran J, Sandercock G, Rumpf MC, Parry DA. Variation in Responses to Sprint Training in Male Youth Athletes: A Meta-analysis. Int J Sports Med. 2017;38(01):1-11.

2. Stojanovic E, Ristic V, McMaster DT, Milanovic Z. Effect of Plyometric Training on Vertical Jump Performance in Female Athletes: A Systematic Review and Meta-Analysis. Sports Med. 2016;47(5):1-12.

3. Redd MJ, Fukuda DH. Utilization of Time Motion Analysis in the Development of Training Programs for Surfing Athletes. Strength Cond J. 2016;38(4):1-8.

4. Lee $\mathrm{SH}$, Kwon TD, Seok CH. Issues of historical recognition of athletes practicing traditional Korean sports: Analysis of recognition level. Korean J Sport Sci. 2017; 26(3):213-21.

5. Barkoukis V, Lazuras L, Kourelis P. A preliminary investigation of the decision making process towards match fixing. Crime, Law Soc Chang. 2020;74(1):45-54.

6. Miziara IM, Silva B, Marques IA, de Sá AAR, Oliveira IM, Pereira A, et al. Analysis of the biomechanical parameters of high-performance of the roundhouse kicks in Taekwondo athletes. Res Biomed Eng 2019;35(3-4):193-201.

7. Pesel H, Ejsmont P, Sobaniec P, et al. Analysis of the HRV Biofeedback Trainings on Stress Level in Athletes Training Sprints. Appl Psychophys Biof. 2015;40(4):373-4.

8. Zhang X. Simulation analysis of athletes' motion recognition based on deep learning method and convolution algorithm. J Intell Fuzzy Syst. 2019;37(1):1-10.

9. Putera SHP, Setijono H, Wiriawan O. Effect of Plyometric Hurdle Hops and Tuck Jump Training on Strength and Leg Muscle Power in Martial Arts Athletes at Kostrad Company-C Malang. Int Res Critics Linguist Educ J. 2019;2(4):566-74.

10. Puce L, Marinelli L, Pierantozzi E, Mori L, Pallecchi I, Bonifazi M, et al. Training methods and analysis of races of a top level Paralympic swimming athlete. J Exerc Rehabil. 2018;14(4):612-20. 